\title{
Methodology for physical modeling of reservoir sedimentation
}

\section{Metodologia para modelagem física do assoreamento em reservatórios}

\author{
Emmanuel Kennedy da Costa Teixeira ${ }^{1}$ (D) Alberto Varotto Rinco ${ }^{1}$ (I), Márcia Maria Lara Pinto Coelho ${ }^{2}$ (1), \\ Aloysio Portugal Maia Saliba ${ }^{2}$ (D), Eber José de Andrade Pinto ${ }^{2}$ (D) \& Leonardo Montes Furtado ${ }^{1}$ \\ ${ }^{1}$ Universidade Federal de São João del-Rei, Ouro Branco, MG, Brasil \\ ${ }^{2}$ Universidade Federal Minas Gerais, Belo Horizonte, MG, Brasil \\ E-mails: emmanuel.teixeira@ufsj.edu.br (EKCT), albertovarotto20@gmail.com (AVR),lara@ehr.ufmg.br (MMLPC), \\ asaliba@ehr.ufmg.br (APMS), eber.andrade@cprm.gov.br (EJAP), leo-montes@hotmail.com (LMF)
}

Received: July 29, 2019 - Revised: March 30, 2020 - Accepted: April 05, 2020

\begin{abstract}
RESUMO
Reservatórios construídos em cursos d'água estão sujeitos a algum grau de assoreamento. Por isso, é importante a estimativa do volume de sedimentos acumulados, visto que esse depósito pode interferir nas funções do reservatório. Uma forma de se fazer isso é utilizando modelos físicos. Entretanto, a partir da literatura existente na área não é possível responder a algumas questões metodológicas que surgem em uma simulação física do assoreamento, como: qual vazão e descarga sólida utilizar? Simular um hidrograma ou uma vazão constante? Assim, esse trabalho teve como objetivo propor uma metodologia de simulação do assoreamento em modelos físicos, de forma que ao se utilizar essa metodologia o assoreamento observado no modelo reduzido pudesse representar o do protótipo. A partir de simulações numéricas e experimentais, optou-se por simular no modelo físico as vazões médias das ondas que compreendiam as vazões máximas. O tempo de escoamento de cada vazão foi de 30 minutos e as descargas sólidas totais utilizadas foram às referentes às vazões médias anuais. Utilizando-se essa metodologia, promoveu-se a simulação do assoreamento no modelo reduzido para o período entre 2013 e 2017, sendo que o resultado obtido foi próximo ao do protótipo, o que indica que a metodologia proposta permitiu representar no modelo reduzido o fenômeno do assoreamento ocorrido no reservatório real.
\end{abstract}

Palavras-chave: Modelo reduzido; HEC-RAS; Hidrograma.

\begin{abstract}
Reservoirs built in watercourses are subject to some degree of silting. Therefore, it is important to estimate the volume of sediment accumulated, since this deposit may interfere with the functions of the reservoir. One way to do this is by using physical models. However, from the existing literature in the area it is not possible to answer some methodological questions that arise in a physical simulation of the silting, such as: which flow and solid discharge to use? Simulate a hydrogram or constant flow? Thus, this work had as objective to propose a simulation methodology of the silting in physical models, so that when using this methodology the observed siltation in the reduced model could represent the one of the prototype. From numerical and experimental simulations, it was chosen to simulate in the physical model the average flows of the waves that comprised the maximum flows. The flow time of each flow was 30 minutes and the total solid discharges used were those referring to the annual average flow rates. Using this methodology, simulation of sedimentation in the reduced model was promoted for the period between 2013 and 2017, and the result obtained was close to that of the prototype, which indicates that the proposed methodology allowed to represent in the reduced model the phenomenon of sedimentation occurred in the actual reservoir.
\end{abstract}

Keywords: Reduced model; HEC-RAS; Hydrogram. 


\section{INTRODUCTION}

Reservoirs can be built for various purposes such as public water supply, power generation, irrigation and flood control (Estigoni et al., 2014). It occurs that these structures formed in natural watercourses are subject to some degree of silting, since the construction of a dam in a river affects its physical and hydraulic characteristics, caused by the reduction of flow velocity and also turbulence, which is due to the increase of the wet area of the river's cross section and the decrease of the slope in the water line (Garg \& Jothiprakash, 2008). Such a reduction has the effect of slowing down the movement of the particle in the direction of the current (Habets et al., 2018) and restricting the resultant of the sustaining forces. In this way, the solid particles can be deposited along the reservoir (Mamede et al., 2018).

The consequences of siltation can be numerous. The reservoir lifespan may decrease (Braga et al., 2019), in addition to affecting the dam safety (Albertin et al., 2010). Lenhardt et al. (2009) show that ecological impacts can also occur, since fine suspended sediments represent an important source of adsorbed nutrients (Maavara et al., 2015), thus accelerating the eutrophication process.

Because of that, it becomes necessary to continuously study the phenomenon of siltation, since sediment behavior is not yet completely theoretically mastered (Schleiss et al., 2016), which makes the phenomenon a challenging problem (Adam et al., 2015). Several researchers have pointed out that reservoir silting is a globally relevant problem that affects the management of water resources in reservoir systems (Mamede et al., 2018). Therefore, over the years, various methods and tools of study have been developed to predict reservoir sedimentation, from empirical to numerical and physical methods (Pillo et al., 2019). There are also techniques that allow the use of geographic information systems and remote sensing (Lopes \& Araújo, 2019).

All these methods are important, because from them it is possible to promote the spatial-temporal estimation of siltation, in order to estimate the volume of material to be sedimented over the years and its non-uniform distribution in the reservoir. Thus the preventive and/or corrective measures can be taken more efficiently, since control of sedimentation in reservoirs should be a priority for decades to come (Annandale, 2011).

As mentioned, a way to estimate siltation is from physical modeling. The interest of using these hydraulic models lies in the possibility of simulating many different situations in a reduced time, thus allowing obtaining optimized, safe and economical solutions. In addition, they allow the testing and optimization of the proposed projects and providing data sets to improve numerical models (Briggs, 2013). The model generally has smaller dimensions than the prototype, which can reduce the cost and facilitate the control of the quantities to be considered. It also must behave in a similar way to the system whose behavior will be predicted. Therefore, the Theory of Hydraulic Similarity is used to establish the basic principles for designing, constructing and operating the physical model. This theory can be found in several sources, such as Julien (2002).

According to Waldron (2008), a major advantage of physical modeling is the ability to replicate situations of complex flows. However, one of the main limitations is due to the effects of the scales used to achieve hydraulic similarity between the prototype and the model. For example, it is often impossible to achieve the similarity between the scale of Froude and Reynolds numbers at the same time, and it is necessary to have a loosening in one of them, and if it is not well studied, the model may not represent the reality of the prototype.

It is found in literary works that have used the physical modeling to study the complex process of sediment transport in watercourses. Alhasan et al. (2016) compared the total solid discharges obtained by equations of the literature with those found in a physical model, in which a dam rupture was promoted. Camnasio et al. (2015) have used a physical model to discuss how different relationships between length and width of shallow rectangular reservoirs can influence flow velocity fields and consequently affect sediment transport. Abderrezzak et al. (2014) discussed how the scale effects of the reduced model can affect bed erosion, and concluded that the volume of eroded material may be underestimated because of the similarity loosening of the Shields number. Lu et al. (2013) show that the geometric scale of the reduced model can be distorted or not. Therefore, they studied the influence of distortion on the deformation of the bed, with the non-distorted models and those with distortion proportions of less than 4 showing the same results of bed deformation. Moran et al. (2013) used a distorted physical model to investigate different sediment supply strategies for the Rhine River. Bieri et al. (2012) did a case study at a hydroelectric plant in Switzerland using a distorted model. Mefford \& Gill (2010) evaluated different forms of habitat creation along a curvilinear deviation caused in a shallow water channel. Ho et al. (2010), in a distorted model, found ways to desalinate a water intake. Armanini et al. (2010) studied the influence of breakwaters to improve the navigation condition on the Po River in Italy.

It happens that, sometimes, still in the design phase of a reservoir, physical modeling is used to estimate its silting for a future scenario, which may or may not make its construction viable. However, none of the works mentioned above proposed to study a methodology for silting simulation using reduced models.

In the literature, there are few options for silting simulation methodologies using reduced models. Therefore, in the state of the art on silting, developed by Hager (2018), the author states that, despite the work developed in the last 30 years, there is still no answer as to which is the correct methodology to be used in estimating silting. He adds that further experimental work needs to be carried out so that the accuracy of silting predictions can be improved. Therefore, it can be observed that the main contribution of this article is to propose a methodology that helps simulate silting in physical models.

One possibility of methodology for physical modeling of silting is from a retro-analysis of the process. According to Machado (2017), retro analysis is an important tool to better understand and analyze the occurring phenomena in order to evaluate and refine the models and methodologies used in the forecast of a phenomenon. Thus, knowing the evolution of silting in the reservoir, in a certain period, it is possible to elaborate a simulation methodology of silting in a reduced model. For this, it is necessary to answer methodological questions, such as: which flow should be simulated? What is the time scale (daily, average, monthly)? What solid discharge(s) should be used? 
One way to answer them is using mathematical modeling associated with the knowledge of hydrosedimentological and topo-bathymetric data. Thus the combination of a numerical modeling and the parameterization of field data can enable the determination of the methodology to be used in the physical model.

Over the years, many mathematical models have been developed. One of them is HEC6, which was developed by the US Army Corps of Engineers in the early 1970s and is the best known one-dimensional mathematical model used in simulating the transport of sediments in rivers and reservoirs (Campos, 2001; Morris \& Fan, 2010). Some mathematical modeling works of reservoirs silting that used HEC6 or its current version, HEC-RAS can be cited, such as Gibson et al. (2017), Kouass1 et al. (2013), Vale (2014), Cortez (2013), Roman (2004), Molino et al. (2001), Nicklow \& Mays (2000) among others. However, none of them promoted a physical simulation of silting combined with the mathematical simulation in HEC-RAS.

Given the above, this work aimed to propose a methodology for simulating silting in physical models, thus promoting experimental advances in the area. In addition, the proposition made was to combine mathematical simulation and parameterization of field data to determine the methodology to be used in the reduced model.

\section{MATERIAL AND METHODS}

\section{Overall presentation of the methodology}

Figure 1 shows a flowchart with the developed methodology. According to what will be described below, to conceive the methodology of silting simulation in the reduced model, the numerical simulation of the silting was used. Thus, it was possible to observe how the silting progressed and thus, determine the flows and total solid discharges that were simulated in the physical model. In other words, from numerical simulations, one can determine the methodology to be used in the physical model.

\section{Description of the Salto do Paraopeba SHP reduced model}

The Salto do Paraopeba Small Hydroelectric Plant (SHP) (Figure 2) had its dam built in the 50s on the Paraopeba River, a tributary of the right bank of the São Francisco River. The plant had its operations started in 1956 with two generating units, the first one consisting of a 1,500 kW generator and a Francis type turbine, the second one consisting of a $970 \mathrm{~kW}$ generator and a Francis twin turbine (SPEC Planejamento, Engenharia e Consultoria Ltda., 2011). The SHP has a drainage area of $2,485 \mathrm{~km}^{2}$, a volume of $1.97 .10^{5} \mathrm{~m}^{3}$, a maximum normal water level of $830.71 \mathrm{~m}$ and an average flow of $47.8 \mathrm{~m}^{3} / \mathrm{s}$. The operation of the SHP has always occurred with interference of sediments until it was deactivated.

In order to study the siltation in this SHP, its reduced model was constructed (Figure 3). The model represents $200 \mathrm{~m}$ downstream of the dam and $1000 \mathrm{~m}$ upstream. This upstream region is a section of hydraulic control (critical flow) and it also limits a sedimentation zone.

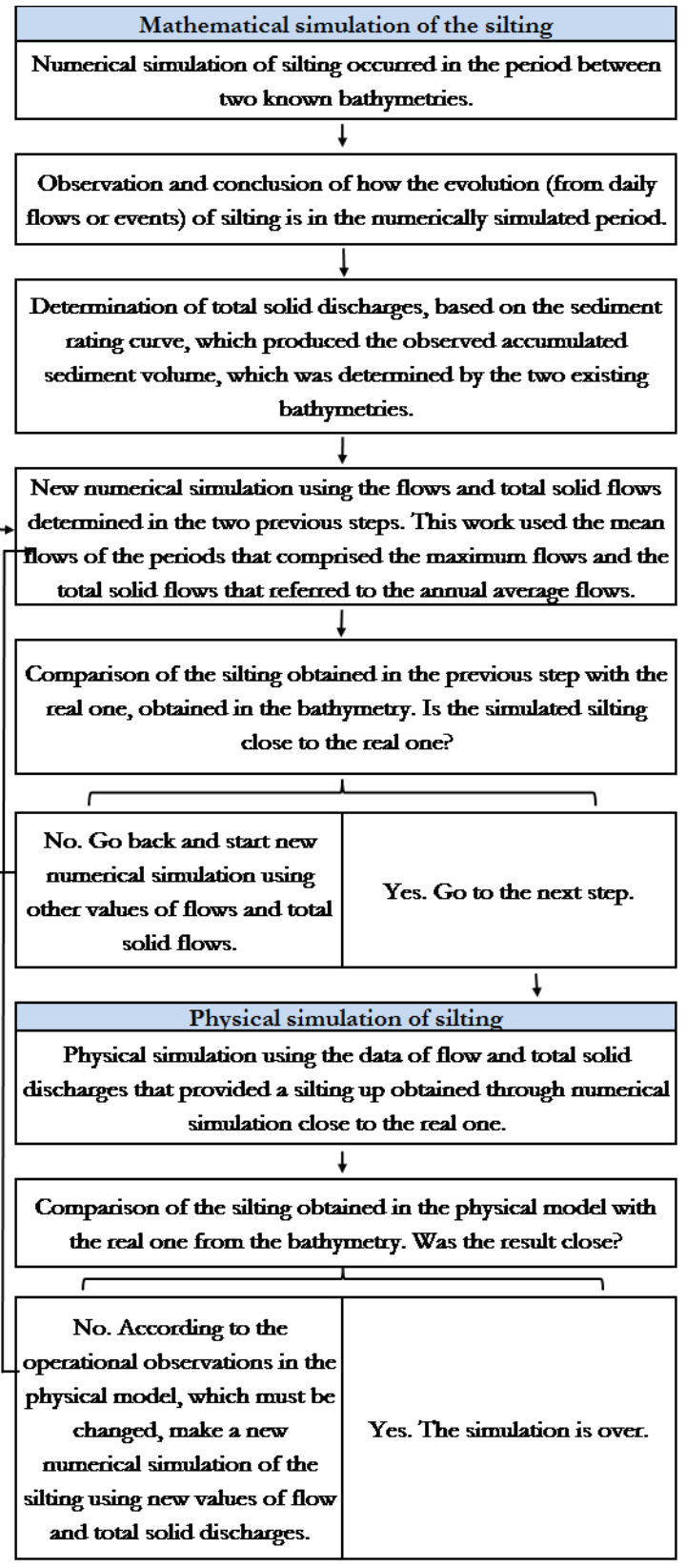

Figure 1. Flowchart of the silting simulation methodology in the reduced model.

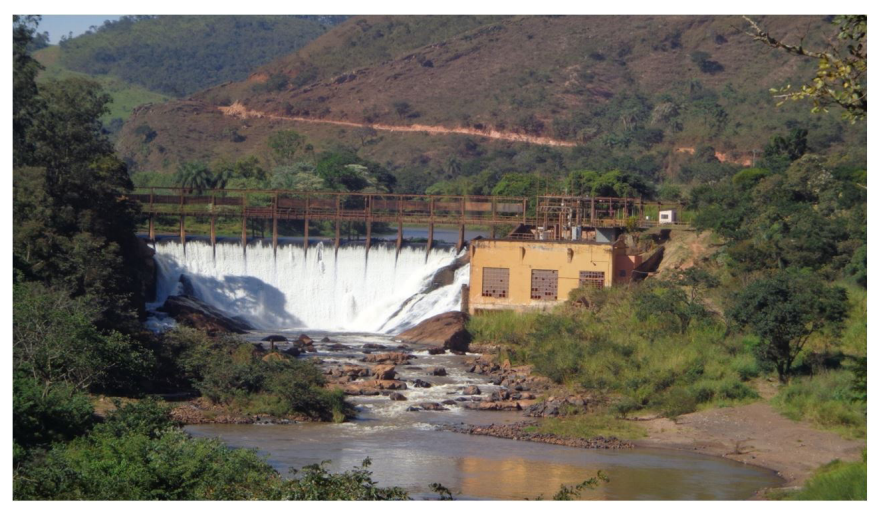

Figure 2. View of the downstream of the Salto do Paraopeba SHP. 
The model dimensioning was carried out using the principles of hydraulic similarity, the scales being calculated according to Julien (2002) and presented in Table 1. From this table it can be observed that the similarity of the scale was not reached through the Froude number and the number of Reynolds, so that the model obeys the similarity only on the scale regarding the number of Froude, being one of its limitations.

All details regarding the reduced model can be found in Carvalho et al. (2014), and only the most important ones will be presented here, since its design is not the objective of this work. It should be noted that in Teixeira (2019) it is shown that the scales

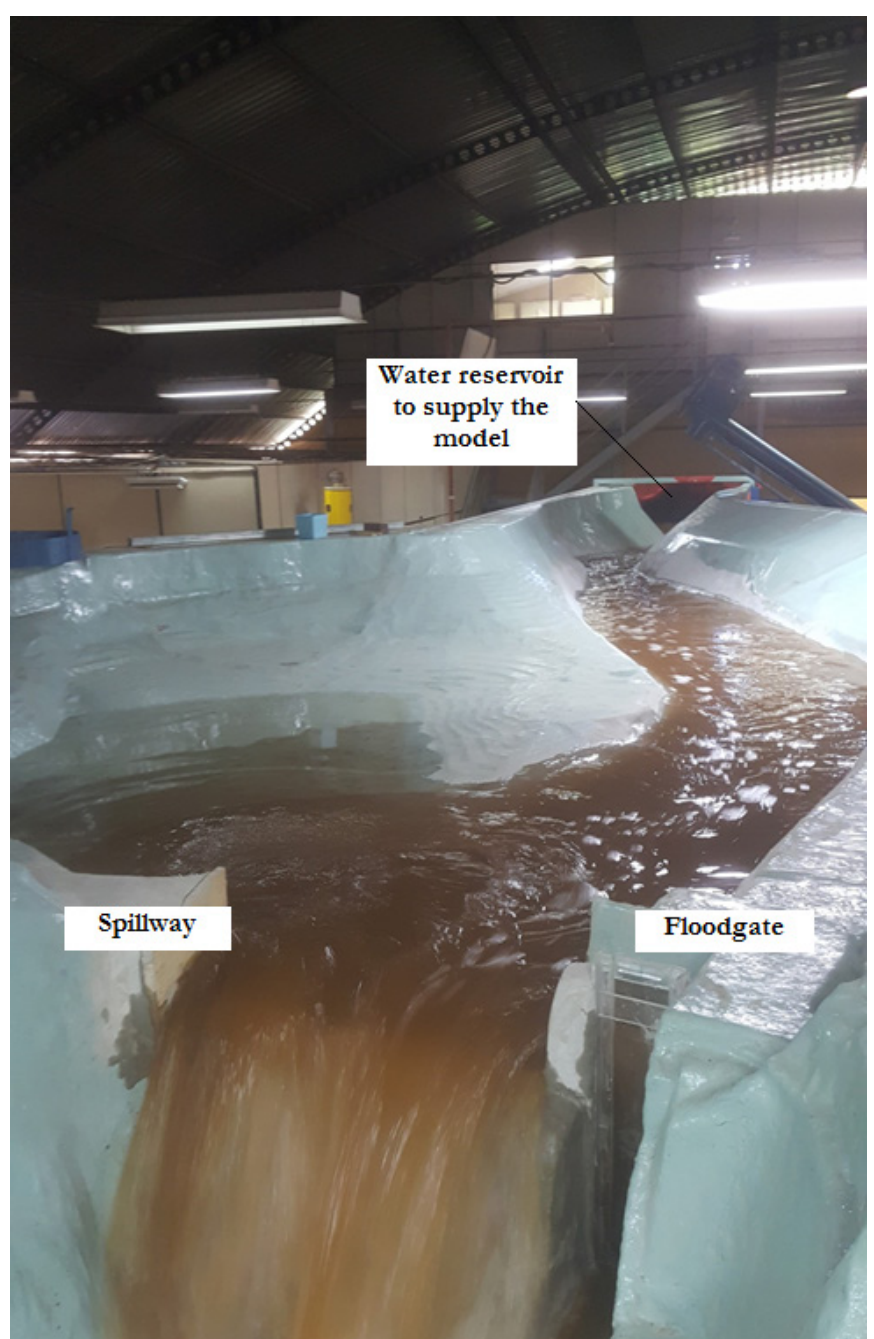

Figure 3. Reduced model of the SHP Salto do Paraopeba.

Table 1. Proposed scales in the design of the reduced SHP model.

\begin{tabular}{lccc}
\hline \multicolumn{1}{c}{ Quantities } & Scale & Real Value & Model Value \\
\hline Length & 99.3 & $1200 \mathrm{~m}$ & $12.1 \mathrm{~m}$ \\
Width & 99.3 & $600 \mathrm{~m}$ & $6.0 \mathrm{~m}$ \\
Depth & 25.0 & $30 \mathrm{~m}$ & $1.2 \mathrm{~m}$ \\
Grain Diameter & 0.4 & $0.45 \mathrm{~mm}$ & $1.13 \mathrm{~mm}$ \\
Time & 2,483 & 5 years & $17.6 \mathrm{~h}$ \\
Froude Number & 1 & - & - \\
Reynolds Number & 125 & - & - \\
Sedimentation rate & 2.5 & $7.9 \mathrm{~cm} / \mathrm{s}$ & $3.1 \mathrm{~cm} / \mathrm{s}$ \\
Sediments Density & 15.8 & 2.65 & 1.11 \\
\hline
\end{tabular}

adopted enabled the reduced model to represent in a realistic way the water and sediments flow.

The sediment used to simulate silting was a rubber granular material, which is industrially produced with the advantages of being insoluble and non-toxic. This rubber was studied by Campello (2017) in order to verify its efficiency as a viable alternative for its use in reduced models.

According to Table 1, the scales for particle diameter, sedimentation speed and sediment density, which were calculated as proposed by Julien (2002), require that the sediment to be used in the reduced model has, respectively, a diameter of $1.13 \mathrm{~mm}$, $3.1 \mathrm{~cm} / \mathrm{s}$ of fall speed and 1.11 of relative density. These values are close to that of the rubber, which has a median diameter $\left(d_{50}\right)$ of $1.2 \mathrm{~mm}$, an average sedimentation speed of $2.7 \mathrm{~cm} / \mathrm{s}$ and a relative density of 1.13 . It is noteworthy that the characteristic values of the rubber were determined by Campello (2017). It is argued that, although the rubber values are not exactly equal to those calculated by the scales, this did not affect the reduced model's ability to represent the silting occurring in the prototype. Teixeira (2019) used this model and he obtained a simulated silting close to the real one, having only the closest cross section to the spillway presented silting in the model farthest from reality.

\section{Parameters to be used in the reduced model}

To study siltation in the SHP reservoir, two bathymetries were used: the ones from the years 2013 and 2017. The simulation between these years, that is, five years of runoff in the prototype, corresponds to approximately $17.6 \mathrm{~h}$ in the reduced model.

The model was divided into 21 cross-sections (Figure 4), in which the silted heights were measured at the end of the simulated period, with section 21 being the one further upstream. It should be noted that the topographies of 2013 and 2017 represent only $300 \mathrm{~m}$ upstream from the dam. Therefore, silting was simulated only in this segment and not in all the reduced model, which represents $1000 \mathrm{~m}$ upstream from the dam.

For the simulation of silting, it was necessary to determine which flow would be used. For this, a numerical simulation of the silting that occurred between 2013 and 2017 was carried out and the behavior of the process was observed over the years. For this simulation, the Hydrologic Engineering Center's River Analysis System (HEC-RAS) software was used, in which the daily flows

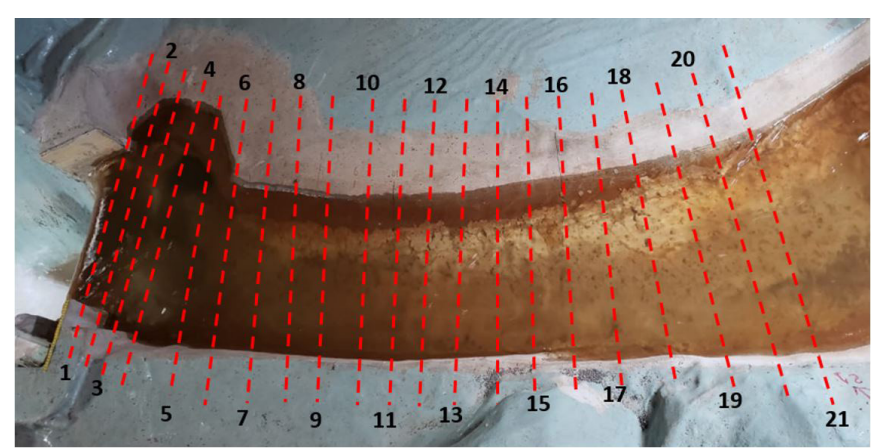

Figure 4. Cross sections in which silting was simulated in the reduced model, its topography being that of the year of 2013. 
of the historical series and the sediments rating curve of the SHP were inserted, after being converted to the scale of the reduced model. The cross sections referring to 2013, the sediment particle size and Manning's coefficient were also inserted.

From the numerical simulation, it was noticed that the sediment movement occurred only on the days of the maximum annual flows, and these flows occurred in one or two days. However, it was operationally infeasible to work with daily flow rates, since one day of the prototype would be equivalent to $35.0 \mathrm{~s}$ of flow in the physical model, which would require changes in the flow rate in that short time interval. Therefore, it was evaluated how the average flows could carry the sediments.

As in the first numerical simulation, using the daily flows, it was observed that the evolution of the silting occurred in periods of maximum flows, a new numerical simulation was promoted, now using the average flows $\left(\mathrm{Q}_{\mathrm{MM}}\right)$ of the periods in which the waves comprised the annual maximum flows. In order to determine the " $Q_{M M}$ " of each hydrological year (2013 to 2017) the daily flow hydrographs were constructed. They are presented in Figure 5, being the hydrological year delimited between October and September, based on the observation of the historical series of daily flows of the SHP.

The waves of Figure 5 were delimited starting and ending at minimum flows, being between them the peak of the maximum flows. It can be seen that the waves have periods of durations of approximately 50 days in the first three years and approximately 30 days in the last two years. Thus, the daily flow averages were made at these time intervals and the " $Q_{M M}$ " were obtained.

As presented in the Results item, the " $Q_{M M}$ " provided a numerically simulated siltation close to the real one, which was obtained by the bathymetry of 2017. Therefore, the experimental silting simulation was performed. For that, besides the flows to be used, it was necessary to determine the runoff period and the total solid discharges that would be used.

To determine the flow period, it is estimated that, in the reduced model, 50 and 30 days are approximately 29 and 17 minutes, respectively. From preliminary tests carried out on the physical model, it was observed that the sediment should be inserted in a less concentrated way, so that a certain mass should be inserted gradually over the longest possible time interval. It was noticed that when inserting a large amount in a short time, there were attractions among the rubber particles (material used to simulate the actual sediment), which made it difficult to be transported.

Thus, although the waves that comprised the maximum flows had different durations, it was chosen to simulate each year with a duration of 29 minutes. With that, the siltation between 2013 and 2017 was simulated for an uninterrupted period of approximately 2.4 hours. This way, physically simulating the " $Q_{M M}$ ", in addition to operationally allowing the flow rate variation, also allowed to reduce the simulated period. Instead of simulating $17.6 \mathrm{~h}$ (five years of the prototype), only $2.4 \mathrm{~h}$ were simulated, therefore, other periods, such as monthly, were not tested.

In order to determine the total solid discharges that would be physically simulated, the SHP bathymetry of the years 2013 and 2017 were compared. The accumulated amount of sediment between these years was $2,085,723.5 \mathrm{~kg}$, which is equivalent to $8.4 \mathrm{~kg}$ in the model (according to the scale factor). Thus, the solid
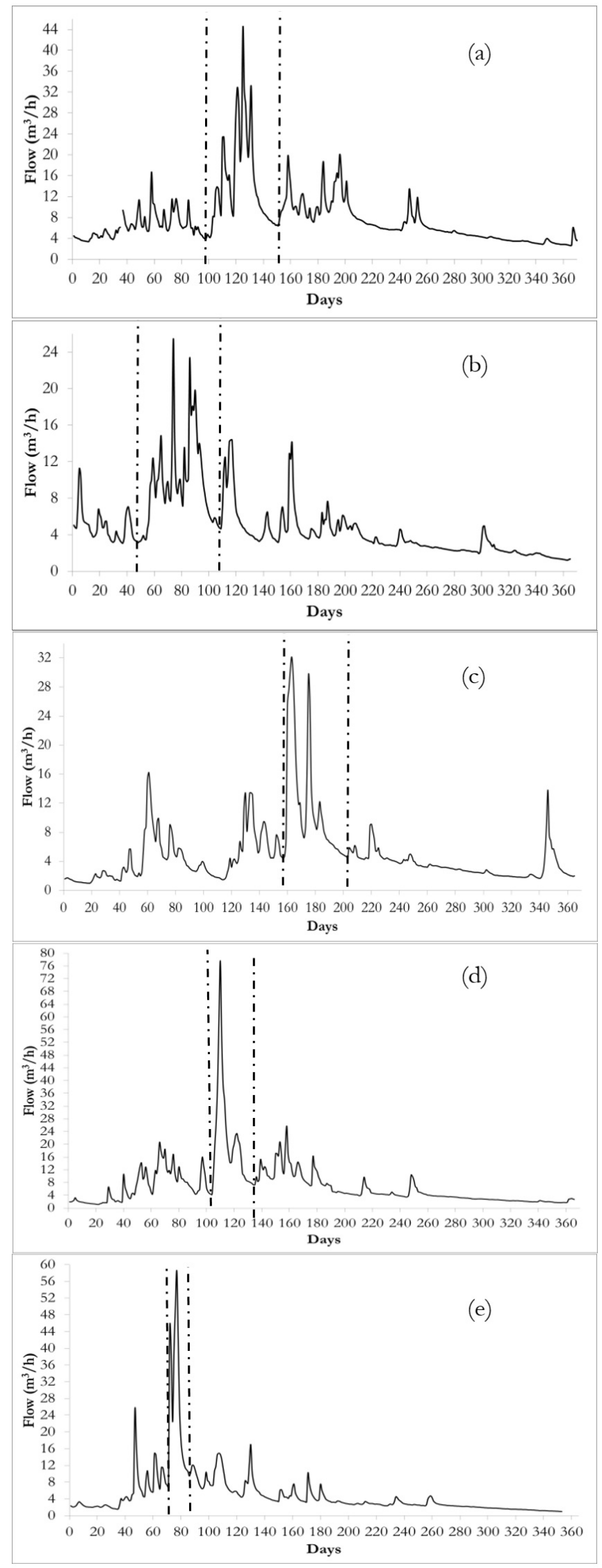

Figure 5. Hydrographs of the hydrological years: (a) 2012-2013; (b) 2013-2014; (c) 2014-2015; (d) 2015-2016; (e) 2016-2017. Between the dashed lines are the waves that comprised the maximum flows. 
discharges that resulted in a quantity of accumulated sediment close to $8.4 \mathrm{~kg}$ were determined. For that, the sediment rating curve of the SHP was used, and converted to the scale of the reduced model.

According to the sediment rating curve, if the total solid discharges $\left(\mathrm{Q}_{\text {STMM }}\right)$ for the " $Q_{M M}$ " were used, at the end of $2.4 \mathrm{~h}$ it should be inserted a cumulative of $41.0 \mathrm{~kg}$ of sediment, much above the real accumulated. It is noteworthy that, from tests carried out on the reduced model, it was observed that flow rates in the order of $40.0 \mathrm{~m}^{3} / \mathrm{h}$, which are larger than the " $Q_{M M}$ ", caused a high sediment discharge. Thus, possibly in the prototype, for the period in question, a high sediment load occurred, however, it did not accumulate, since the higher daily flows promoted their transport and, consequently, the sediment discharge. However, in the reduced model it was not feasible to work with all this rubber mass $(41.0 \mathrm{~kg})$, since daily flows were not simulated. Thus, at the end of the experiment period, there would be a much larger accumulated amount than the actual one $(8.4 \mathrm{~kg})$, since the " $Q_{M M}$ " would not be able to promote excessive sediment flow-through.

Thus, based on the sediment rating curve, it was noted that the total solid discharges $\left(\mathrm{Q}_{\text {STMA }}\right)$ referring to the average annual flows $\left(\mathrm{Q}_{\mathrm{MA}}\right)$ provided a sediment accumulation of $9.2 \mathrm{~kg}$, which is slightly higher than the real $(8.4 \mathrm{~kg})$. However, in the reduced model, a small part of this sediment was discharged, due to the formation of a vortex near the spillway, so that at the end of $2.4 \mathrm{~h}$, the mass retained in the model was very close to the expected one.

In Table 2, in order to summarize the information previously presented, the values used to physically simulate the siltation between 2013 and 2017 are shown. The flows used were the average of periods that covered the maximum annual flows " $Q_{M M}$ ". The total solid discharges " $\mathrm{Q}_{\text {STMA }}$ " were those referring to the average annual flows and not those referring to " $Q_{M M}$ ", since the latter, for the period from 2013 to 2017, would produce an accumulated mass of sediment much greater than the real one. The flow durations were constant and equal to 29.0 minutes, and the accumulated masses (MA) of sediments that are presented in the table were introduced throughout each period.

\section{Simulation of sediment on the reduced model}

The sediment was inserted in a single point - in the most upstream section of the simulated stretch (section "21" of Figure 4). This was done by following the same procedure adopted by HEC-RAS, which, as explained, was used to observe the sediment behavior in the studied period of time. In addition, since sedimentation was being simulated in a $300.0 \mathrm{~m}$ stretch of the reservoir $(3.0 \mathrm{~m}$ in the model), it is possible that the main

Table 2. Data used in the operation of the physical model for simulation of silting between 2013 and 2017.

\begin{tabular}{cccc}
\hline Year & $\mathbf{Q}_{\text {MM }}\left(\mathbf{m}^{3} / \mathbf{h}\right)$ & $\mathbf{Q}_{\text {STMA }}(\mathbf{t} / \mathbf{d})$ & $\mathbf{M A ~ ( k g )}$ \\
\hline 2013 & 27.2 & 0.021 & 3.0 \\
2014 & 13.1 & 0.002 & 0.2 \\
2015 & 23.0 & 0.008 & 1.2 \\
2016 & 31.5 & 0.024 & 3.4 \\
2017 & 25.3 & 0.010 & 1.4 \\
\hline
\end{tabular}

contribution of sediment is the one that comes from upstream, that is, the lateral contribution is small, given that in the visit to the SHP there were no erosions in the margins along this stretch.

The distribution and development of sedimentation in the reduced model over the time interval $(2.4 \mathrm{~h})$ were monitored through photos, videos and sediment deposition measurements, the final result being compared to the bathymetry data of 2017 . The measurement of the deposits was made with the aid of a Photoelectric Sensor. This sensor has a display that shows the distance between the apparatus and the surface measured, in this case, the sediment deposition. Thus, at the end of $2.4 \mathrm{~h}$, the reduced model was carefully drained so the topography of the sediments was not changed and the associated heights were measured along the 21 cross sections of interest. The measurement was made at the lowest point of the cross section, in order to compose the longitudinal profile of the silting in this reservoir.

\section{RESULTS AND DISCUSSIONS}

In order to observe the flow values that caused the transport and deposition of solid particles in the reservoir of the reduced model of the SHP, the silting behavior in the period comprehended between 2013 and 2017 was analyzed, using the daily flows of the historical series of the SHP, by means of HEC-RAS. The result is in Figure 6. From the image, it can be noted that the silting modeled in HEC-RAS is the same as the real one, obtained by the bathymetry of 2017, which indicates good calibration of the numerical model. Gibson et al. (2017), Kouassi et al. (2013), Vale (2014), Cortez, (2013), Remo \& Pinter (2007), Roman (2004), Molino et al. (2001) and Nicklow \& Mays (2000) also simulated the siltation using HEC-RAS and obtained results close to the real data.

The daily flow simulation performed with the HEC-RAS software, from 2013 to 2017, showed that sediment movements occurred only during rainy periods, which included each year's maximum flows. This movement through events was also observed by Moran et al. (2013), when studying strategies for supplying sediments to the Rhine River.

In Figure 7, from the HEC-RAS simulation, the evolution of silting is presented for the rainy periods of the hydrological years (2013-2014, 2014-2015, 2015-2016 and 2016-2017). It should be emphasized that the curves of the figure represent one or

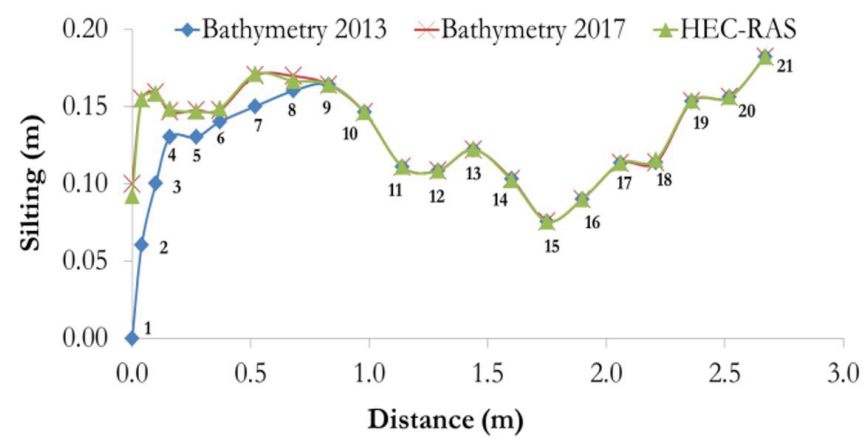

Figure 6. Longitudinal profile of the real silting in the SHP and the one simulated in HEC-RAS, using the daily flows for the years 2013 and 2017 (values converted to the scale of the reduced model). 
two days after the occurrence of the maximum flow, because it was in the period with smaller flows than the maximum that the sediment was deposited in the reservoir. Besides, the longitudinal profile of the silting remained unchanged between the days of the maximum annual flows.

It is emphasized that the silting evolution presented in Figure 7 represents the mathematically simulated for the SHP. In the reduced model this evolution from one year to another was not measured, so that the experiment was not interrupted, thus only the final siltation was measured.

Also it can be observed from Figure 7 that the silted height suffered greater variation when the maximum flow of the hydrological year 2015-2016 occurred. This is due to the fact that this year had a higher peak flow than in previous years (Figure 5). Consequently, this caused a higher load of sediments affluent to the reservoir and caused the silted profile to change more expressively.

In Figure 7, it can be noted that at each maximum flow period, of each hydrological year, the silting accumulated until there was a result for the last year (2016-2017), close to the real one (2017 bathymetry). Therefore, a new simulation was made in HEC-RAS. However, instead of using the daily flows, as in the previous one, whose result was presented in Figure 7, the mean flows $\left(\mathrm{Q}_{\mathrm{MM}}\right)$ of the periods that comprised the maximum flows of each hydrological year were used. The result is shown in Figure 8.

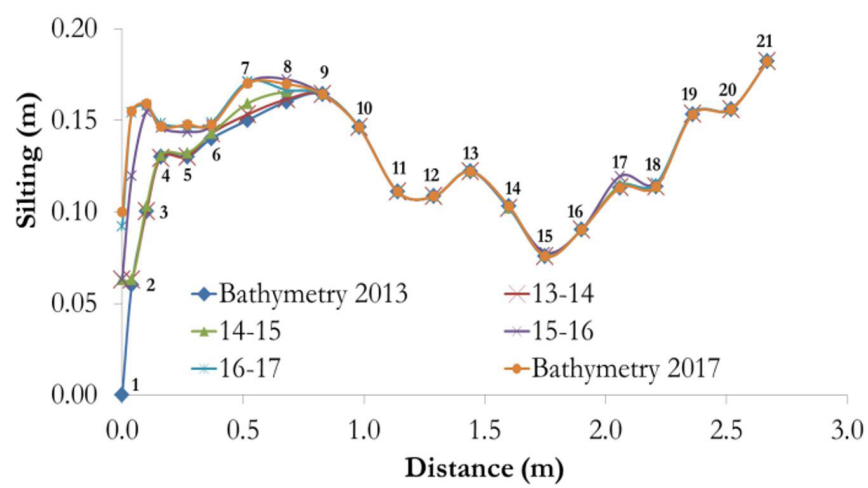

Figure 7. Simulation in HEC-RAS of the silting evolution for the periods that comprised the maximum flows of each hydrological year (values converted to the scale of the reduced model).

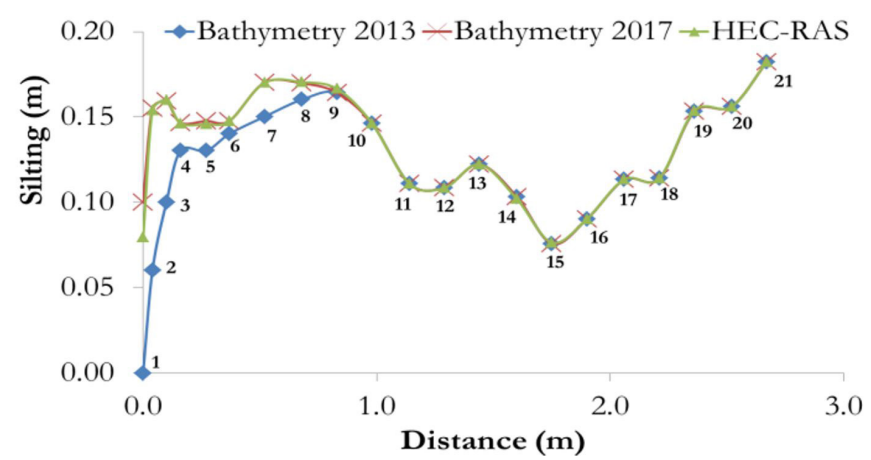

Figure 8. Longitudinal profile of the actual silting of the SHP (2017 bathymetry) and the HEC-RAS simulated silting, using the mean flows of the maximum periods, for the years 2013 and 2017 (values converted to the scale of the reduced model).
It can be observed in Figure 8 that the silting which was simulated in HEC-RAS was similar to that of the bathymetry of 2017 for almost all sections, with the largest difference being of $2.0 \mathrm{~cm}$ in section " 1 ", which represents $50.0 \mathrm{~cm}$ in the prototype. This section was possibly affected due to its proximity to the spillway, since it is only $2.5 \mathrm{~cm}$ away from this structure (value for the reduced model). Thus the lines of currents that leave the bottom of this section and flow through the spillway can promote the resuspension of sediments and their consequent spill. It should be noted that this sediment resuspension was also observed in the physical model and corroborates with what was observed by Armanini et al. (2010), which stated that the physical model which was used by them allowed the reproduction of the sediments in suspension as in the prototype. Moran et al. (2013) also concluded that the sediments were resuspended when higher flows occurred.

As in the HEC-RAS simulation the " $Q_{M M}$ " resulted in good concordance with the real, in the reduced model these flows were also used to simulate what happened between 2013 and 2017. The simulation was repeated twice to verify the efficiency of its execution. The result is shown in Figure 9. As the two replicates of the procedure presented similar results, the figure shows only the average of the silting occurred in the physical model.

It can be seen from Figure 9 that sedimentation occurred in the last ten cross-sections (section " 1 " to " 10 ") while in the

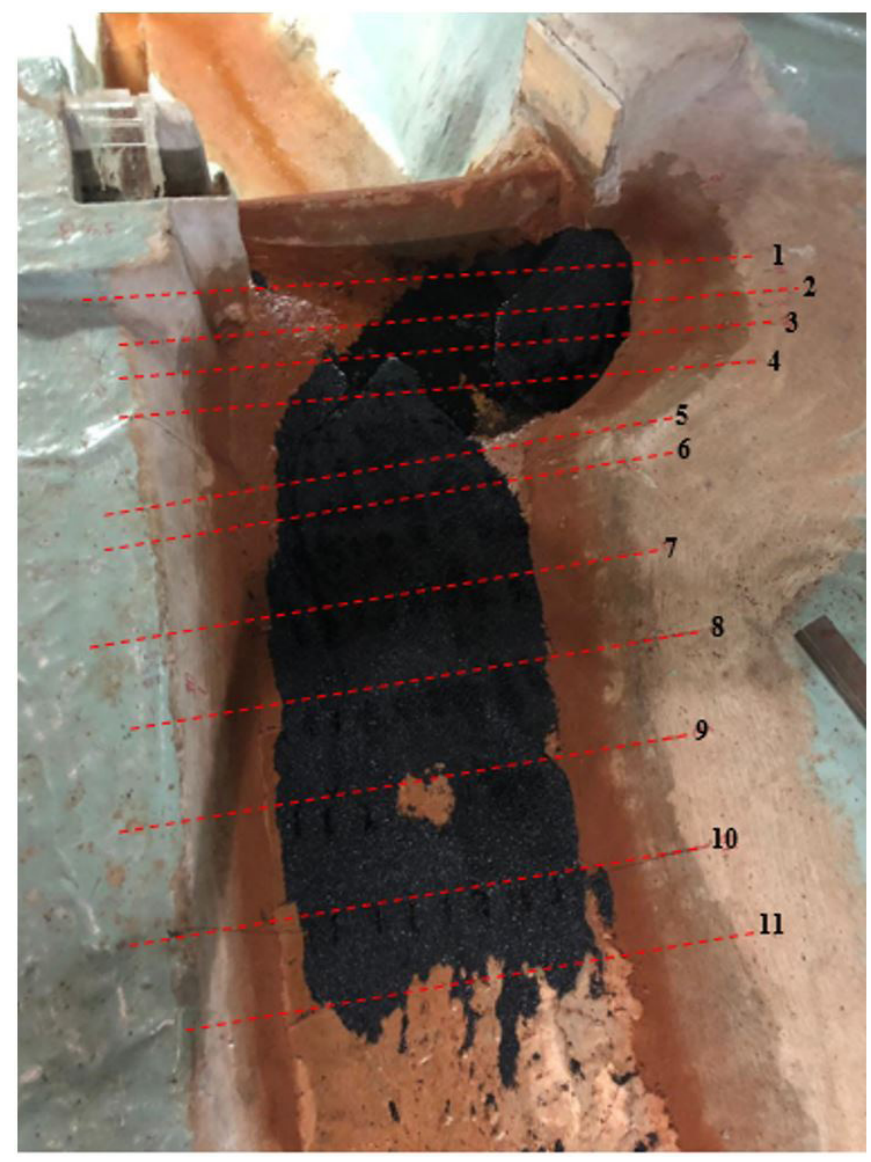

Figure 9. Sedimentation obtained in the reduced model using the average flows of the maximum flow periods, for the period between 2013 and 2017. 
prototype it was among the last nine sections. However, the sediment accumulated in section " 10 " consists of a thin layer of the order of $1.0 \mathrm{~mm}$, which represents $2.5 \mathrm{~cm}$ in the SHP, that is, a very small value. Thus, in spite of the silting occurring in this section, it is observed that the procedure developed and used in this work represented the real silting well, as described next.

Figure 10 shows the longitudinal profile of the silting as a result of the measurements made in the sections shown in Figure 9. It should be noted that the measurements of the silted height were made at the lowest point of the cross section, this being the same procedure used by HEC-RAS for the composition of the simulated longitudinal profile.

It can be seen from Figure 10 that the silting of the physical model approached the real one, indicating that the methodology used allowed what happened in relation to the silting of the prototype in the period from 2013 to 2017 to be reproduced. Bieri et al. (2012), using a reduced model to simulate sediment transport in the Rhone river, between the years of 1997 and 2005, also used a hydrograph with flows referring to maximum flow events and concluded that they obtained satisfactory morphological results, so that the silting behavior was similar in the model and in the prototype. Kökpinar et al. (2007) obtained that the behavior of silting occurred in the field was similar to the one obtained in the studies of the physical model, although the magnitude measured in the field was higher than the one produced by the physical model.

It is observed in Figure 10 that the two sections where the result of sedimentation in the reduced model distanced more from the bathymetry of 2017 were " 3 " and " 4 ", but it can be noted that the excess of sediments in section " 4 " is almost the same as the one that lacks in section " 3 ". Maynord (2006) states that the use of a basic procedure, such as that adopted in this article can slightly reduce the accuracy of the physical model, but there must be similarities between the model's predictions and what occurs in the prototype. Therefore, when proposing a methodology it may happen that the silting is not the same between model and prototype in all sections, as observed in sections " 3 " and " 4 ", but this fact does not fail to validate the proposed methodology, since there was a similarity in the other cross sections.

A possible reason that may have affected the silting in sections " 3 " and " 4 " is the fact that the model does not obey the

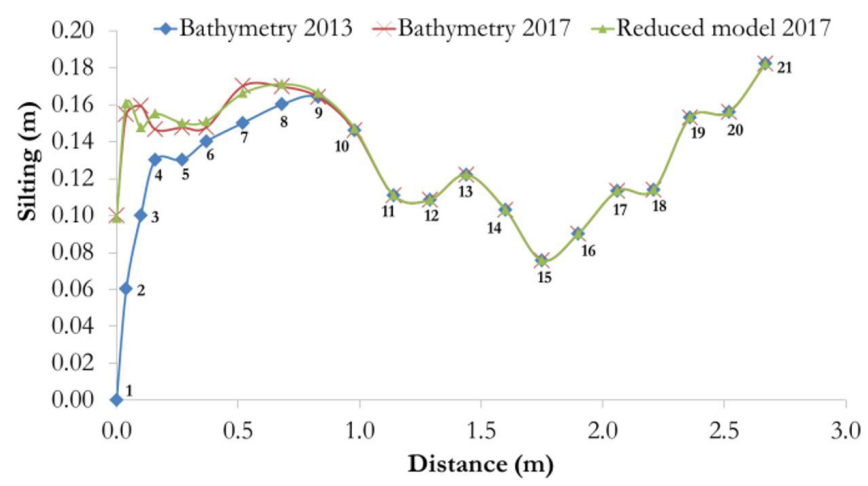

Figure 10. Longitudinal profile of the SHP's actual siltation (bathymetry of 2017) and the one observed in the reduced model (mean of the two replicates of the experiment), using the average flows of maximum flow periods for the years of 2013 to 2017. similarity regarding the Reynolds Number (Re). Abderrezzak et al. (2014) show that it is not necessary to preserve this similarity between the model and the prototype, if the value in the model is high enough to ensure that the flow regime is hydraulically rough. For this regime to occur, American Society of Civil Engineers (2000) observes that the effects of viscosity become less important for " $R e$ " around a value of 60 . This is consistent with the suggestions of Chanson (1999) and Yalin (1971) who presented values of 100 and 70, respectively. Ashworth et al. (1994) show that values of the order of 5 and 15 are already enough for the hydraulically rough regime to occur in physical models. In the SHP reduced model, in sections " 3 " and " 4 ", for the used flows, the "Re" ranged from 26 to 62 .

It should be emphasized that it was observed during the simulated sedimentation procedure in the reduced model that if the runoff time was slightly higher than the stipulated 29.0 minutes, the height of the sediment deposits in these sections would tend to be equal to the real one. However, it was decided to maintain the previously established time to standardize the developed methodology.

\section{CONCLUSION}

Throughout this work the fundamentals that guided the development of this research were presented, which had as objective the development of a methodology for simulation of sedimentation occurred in reservoirs in a reduced model. Based on the results obtained, the following can be stated:

- The numerical simulation allowed to observe that the silting in the SHP occurred due to maximum flow events. So, it was possible to determine which flow values and durations were used in the physical modeling of the silting;

- From two bathymetries performed at the SHP it was possible to determine the volume of accumulated sediments. Having this information, based on the SHP sediment rating curve, the solid discharges used in the reduced model were determined;

Based on the physical modeling performed, the mean flow rates of the waves that comprised the maximum flows allowed sediment transport and their subsequent deposition. The total solid discharges obtained from the average annual flows resulted in an accumulated sediment load in the physical model close to that of the real one;

The siltation in the reduced model, determined for the 2013-2017 period, was similar to the SHP 2017 bathymetry.

In view of this, the combination of mathematical modeling and parameterization of field data allowed the development of a methodology for physical simulation of silting. Thus, the adopted procedure reproduced the phenomenon that occurred in the prototype and presents itself as a possibility to be replicated, or at least tested by other authors who are developing works which objective is to physically simulate silting in reservoirs. 


\section{ACKNOWLEDGEMENTS}

To the Federal University of São João del-Rei for financial support and the postgraduate program in Sanitation, Environment and Water Resources of the Federal University of Minas Gerais.

\section{REFERENCES}

Abderrezzak, K. E. K., Moran, A. D., Mosselman, E., Bouchard, J. P., Habersack, H., \& Aelbrecht, D. (2014). A physical, movablebed model for non-uniform sediment transport, fluvial erosion and bank failure in rivers. Journal of Hydro-environment Research, 8(2), 95-114. http://dx.doi.org/10.1016/j.jher.2013.09.004.

Adam, N., Erpicum, S., Archambeau, P., Pirotton, M., \& Dewals, B. (2015). Stochastic modeling of reservoir sedimentation in a semi-arid watershed. Water Resources Management, 29(3), 785-800. http://dx.doi.org/10.1007/s11269-014-0843-4.

Albertin, L. L., Matos, A. J. S., \& Mauad, F. F. (2010). Calculation of volume and analysis of sediments deposition of the Três Irmãos reservoir. Brazilian Journal of Water Resources, 15(4), 57-67.

Alhasan, Z., Jandora, J., \& Riha, J. (2016). Comparison of specific sediment transport rates obtained from empirical formulae and dam breaching experiments. Environmental Fluid Mechanics, 16(5), 997-1019. http://dx.doi.org/10.1007/s10652-016-9463-2.

American Society of Civil Engineers - ASCE. (2000). Hydraulic modeling: concepts and practice (ASCE Manuals and Reports on Engineering Practice, No. 97). Reston: ASCE.

Annandale, G. (2011). Going full circle. International Water Power \& Dam Construction, 63(4), 30-34.

Armanini, A., Sartori, F., Tomio, G., Cerchia, F., \& Vergnani, M. (2010). Analysis of a fluvial groynes system on hydraulic scale model. In River Flow 2010: Proceedings of the International Conference on Fluvial Hydraulics. Karlsruhe: Bundesanst für Wasserbau.

Ashworth, P. J., Best, J. L., Leddy, J. O., \& Geehan, G. W. (1994). The physical modelling of braided rivers and deposition of finegrained sediment. In M. J. Kirkby (Ed.), Process models and theoretical geomorphology (pp. 115-139). Chichester: John Wiley and Sons Ltd.

Bieri, M. D., Muller, M., Boillat, J. L., \& Schleiss, A. J. (2012). Modeling of sediment management for the Lavey Run-of-River HPP in Switzerland. Journal of Hydraulic Engineering, 138(4), 340347. http://dx.doi.org/10.1061/(ASCE)HY.1943-7900.0000505.

Braga, B. B., Carvalho, T. R. A., Brosinsky, A., Foerster, S., \& Medeiros, P. H. A. (2019). Fromwaste to resource: cost-benefit analysis of reservoir sediment reuse for soil fertilization in a semiarid catchment. The Science of the Total Environment, 670, 158-169. PMid:30903890. http://dx.doi.org/10.1016/j.scitotenv.2019.03.083.

Briggs, M. J. (2013). Basics of physical modeling in coastal and bydraulic engineering (ERDC/CHL CHETN-XIII-3). Vicksburg: US Army Engineer Research and Development Center.
Camnasio, E., Orsi, E., \& Schleiss, A. J. (2015). Experimental study of velocity fields in rectangular shallow reservoirs. Journal of Hydraulic Research, 49(3), 352-358. http://dx.doi.org/10.1080 /00221686.2011.574387.

Campello, B. S. C. (2017). Estudo da velocidade de queda e do início do movimento das partículas de borracha e areia (Dissertação de mestrado). Escola de Engenharia, Universidade Federal de Minas Gerais, Belo Horizonte.

Campos, R. (2001). Three-dimensional reservoir sedimentation model. Newcastle: University of Newcastle.

Carvalho, L. S., Saliba, A. P. M., Santos, R. S. F., Haselbauer, M., Velasco, D., Viana, E. M. F., Martinez, C. B., Costa, M. E. F., \& Freitas, F. L. (2014). Development of the reduced model project of Salto do Paraopeba SHP. In XXVI Latin American Hydraulic Congress. Santiago, Chile: IAHR.

Chanson, H. (1999). The bydraulics of flow in open channels. London: Arnold.

Cortez, J. R. (2013). Desempenho de modelos numéricos em estudos de assoreamento de reservatórios: caso UHE Aimorés (Dissertação de mestrado). Escola de Engenharia, Universidade Federal de Minas Gerais, Belo Horizonte.

Estigoni, M. V., Matos, A. J. S., \& Mauad, F. F. (2014). Assessment of the accuracy of different standard methods for determining reservoir capacity and sedimentation. Journal of Soils and Sediments, 14(7), 1224-1234. http://dx.doi.org/10.1007/s11368-013-0816-x.

Garg, V., \& Jothiprakash, V. (2008). Estimation of useful life of a reservoir using sediment trap efficiency. Journal of Spatial Hydrology, 8(2), 1-14.

Gibson, S., Sánchez, A., Piper, S., \& Brunner, G. (2017). New one-dimensional sediment features in HEC-RAS 5.0 and 5.1. In Proceedings of the World Environmental and Water Resources Congress (pp. 192-206). Reston: American Society of Civil Engineers.

Habets, F., Molénat, J., Carluer, N., Douez, O., \& Leenhardt, D. (2018). The cumulative impacts of small reservoirs on hydrology: a review. The Science of the Total Environment, 643, 850-867. PMid:30189581. http://dx.doi.org/10.1016/j.scitotenv.2018.06.188.

Hager, W. H. (2018). Bed-load transport: advances up to 1945 and outlook into the future. Journal of Hydraulic Research, 56(5), 596-607. http://dx.doi.org/10.1080/00221686.2017.1405370.

Ho, J., Coonrod, J., Gill, T., \& Mefford, B. (2010). Case study: movable bed model scaling for bed load sediment exclusion at intake structure on Rio Grande. Journal of Hydraulic Engineering, 136(4), 247-250. http://dx.doi.org/10.1061/(ASCE)HY.19437900.0000149

Julien, P. Y. (2002). River mechanics (1st ed.). Cambridge: Cambridge University Press. http://dx.doi.org/10.1017/CBO9781139164016. 
Kökpinar, M. A., Darama, Y., \& Güler, I. (2007). Physical and numerical modeling of shoreline evaluation of the Kiz1lirmak River mouth, Turkey. Journal of Coastal Research, 23(2), 445-456. http://dx.doi.org/10.2112/04-0178.1.

Kouass1, K. L., Kouame, K. I., Konan, K. S., Sanchez Angulo, M., Deme, M., \& Meledje, N. D. H. E. (2013). Two-dimensional numerical simulation of the hydro-sedimentary phenomena in Lake Taabo, Côte d'ivoire. Water Resources Management, 27(12), 4379-4394. http:/ / dx.doi.org/10.1007/s11269-013-0417-x.

Lenhardt, M., Markovic, G., \& Gacic, Z. (2009). Decline in the index of biotic integrity of the fish assemblage as a response to reservoir aging. Water Resources Management, 23(9), 1713-1723. http://dx.doi.org/10.1007/s11269-008-9348-3.

Lopes, J. W. B., \& Araújo, J. C. (2019). Simplified method for the assessment of siltation in semiarid reservoirs using satellite imagery. Water, 11(5), 1-18. http://dx.doi.org/10.3390/ w11050998.

Lu, J., Liao, X., \& Zhao, G. (2013). Experimental study on effects of geometric distortion upon suspended sediments in bending channels. Sedimentary Geology, 294, 27-36. http:// dx.doi.org/10.1016/j.sedgeo.2013.05.006.

Maavara, T., Parsons, C. T., Ridenour, C., Stojanovic, S., Dürr, H. H., Powley, H. R., \& Van Cappellen, P. (2015). Global phosphorus retention by river damming. Proceedings of the National Academy of Sciences of the United States of America, 112(51), 15603-15608. PMid:26644553. http://dx.doi.org/10.1073/pnas.1511797112.

Machado, N. C. (2017). Retroanálise da propagação decorrente da ruptura da barragem do fundão com diferentes modelos numéricos e hipóteses de simulação (Dissertação de mestrado). Escola de Engenharia, Universidade Federal de Minas Gerais, Belo Horizonte, .

Mamede, G. L., Guentner, A., Medeiros, P. H. A., Araújo, J. C., \& Bronstert, A. (2018). Modeling the effect of multiple reservoirs on water and sediment dynamics in a semiarid catchment in Brazil. Journal of Hydraulic Engineering, 23(23), 1-13.

Maynord, S. T. (2006). Evaluation of the micromodel: an extremely small-scale movable bed model. Journal of Hydraulic Engineering, 132(4), 343-353. http://dx.doi.org/10.1061/ (ASCE)0733-9429(2006)132:4(343).

Mefford, B., \& Gill, T. (2010). Physical bydraulic model proposal for US Army Corps of Engineers Missouri river bend model (Hydraulic Laboratory Report HL-2010-05). Washington: U.S. Department of the Interior, Bureau of Reclamation.

Molino, B., Greco, M., \& Rowan, J. S. A. (2001). 2-D reservoir routing model: sedimentation history of Abbeystead Reservoir, U. K. Water Resources Management, 15(2), 109-122. http:/ / dx.doi. org/10.1023/A:1012550625107.
Moran, A. D., Abderrezzak, K. E. K., Mosselman, E., Habersack, H., Lebert, F., Aelbrecht, D., \& Laperrousaz, E. (2013). Physical model experiments for sediment supply to the old Rhine through induced bank erosion. International Journal of Sediment Research, 28(4), 431-447. http://dx.doi.org/10.1016/ S1001-6279(14)60003-2.

Morris, G. L., \& Fan, J. (2010). Reservoir sedimentation handbook: design and danagement of dams, reservoirs, and watersheds for sustainable use. New York: McGraw-Hill.

Nicklow, J. W., \& Mays, L. W. (2000). Optimization of multiple reservoir networks for sedimentation control. Journal of Hydraulic Engineering, 126(4), 232-242. http://dx.doi.org/10.1061/ (ASCE)0733-9429(2000)126:4(232).

Pillo, R., Girolamo, A. M., \& Todisco, M. T. (2019). Modelling the silting-up of a small reservoir fed by a temporary river: the Torrebianca reservoir study case (Puglia, SE Italy). Journal of Materials and Environmental Sciences, 10(3), 225-233.

Remo, J. W. F., \& Pinter, N. (2007). Retro-modeling the Middle Mississippi river. Journal of Hydrology, 337(3-4), 421-435. http:/ / dx.doi.org/10.1016/j.jhydrol.2007.02.008.

Roman, V. (2004). Análise do equilíbrio morfológico em rios regularizados: modelagem matemática unidimensional do transporte de sedimentos no rio São Francisco (Dissertação de mestrado). Escola de Engenharia, Universidade Federal de Minas Gerais, Belo Horizonte.

Schleiss, A. J., Franca, M. J., Juez, C., \& Cesare, G. (2016). Reservoir sedimentation. Journal of Hydraulic Research, 54(6), 595-614. http://dx.doi.org/10.1080/00221686.2016.1225320.

SPEC Planejamento, Engenharia e Consultoria Ltda. (2011). Relatório final do Projeto Básico: PCH Salto Paraopeba (Vol. 1, Relatório no. 11.118-RT-GT10-3001). Belo Horizonte: SPEC.

Teixeira, E. K. C. (2019). Simulação estocástica na estimativa do assoreamento em reservatórios (Tese de doutorado). Escola de Engenharia, Universidade Federal de Minas Gerais, Belo Horizonte.

Vale, V. L. (2014). Reconstituição da calha natural do reservatório da PCH Salto do Paraopeba (Dissertação de mestrado). Escola de Engenharia, Universidade Federal de Minas Gerais, Belo Horizonte.

Waldron, R. L. (2008). Physical modeling of flow and sediment transport using distorted scale modeling (Master's thesis). Louisiana State University and Agricultural and Mechanical College, Louisiana.

Yalin, M. S. (1971). Theory of hydraulic models. London: MacMillan. http://dx.doi.org/10.1007/978-1-349-00245-0. 


\section{Authors contributions}

Emmanuel Kennedy da Costa Teixeira: Work creator. Executor of all work steps and article text writer.

Alberto Varotto Rinco: Execution of all stages of the procedures performed in the laboratory. Participated in the elaboration of the methodology and analysis of the results.

Márcia Maria Lara Pinto Coelho: PhD advisor of the first author of this paper. Guiding all stages of the work. Revision of the text of the article.
Aloysio Portugal Maia Saliba: Participated in the conception of the methodology of the article and in the discussion of the results achieved. Reviewer of the text of the article.

Eber José de Andrade Pinto: Guiding all stages of the work. Reviewer of the text of the article.

Leonardo Montes Furtado: Execution of the work. He participated effectively in all the numerous tests done in the laboratory. 